\title{
Protective Effects of Vitamin E on Memantine Adverse Effects
}

\author{
Gamal El-Din Shams ${ }^{1}$, Mohamed H. Khairy ${ }^{1}$, Mohammed A. Saleh ${ }^{2}$, Samar A. Antar ${ }^{3 *}$ \\ ${ }^{1}$ Pharmacology Department, Faculty of Veterinary, Zagazig University, 44511, Egypt. \\ ${ }^{2}$ Pharmacology Department, Faculty of Pharmacy, Mansoura University, Mansoura, Egypt \\ ${ }^{3}$ Pharmacology Department, Faculty of Pharmacy, Horus university
}

\begin{abstract}
This study to evaluate the protective effect of Vitamin E $(1 \mathrm{mg} / \mathrm{kg}$, P.O. once daily) on Memantine adverse effects $(0.36 \mathrm{mg} / \mathrm{kg}$, P.O. once daily) and its effect on liver, kidney, blood and antioxidant enzymes for three weeks. Then tissue and blood samples were collected on 1st, 2nd and 3rd weeks post-treatment to assess the protective effect of Vitamin E. Our results indicated that Vitamin E has hepato-nephro-protective and there was a decrease in the elevation of liver enzymes caused by Memantine like ALT, AST and ALP and kidney parameters like creatinine, urea and uric acid, and there was a normalize in all blood parameters which decrease by Memantine and finally there was a significant increase in antioxidant enzymes like CAT, SOD, GPX and a significant decrease in MDA, beside showing decrease in hepatic steatosis (arrowhead) and decrease in the apoptotic and necrotic cells mostly within the centrolobular caused by Memantine administration, as demonstrated by hepatic histopathology. Also, showing decrease in tubular basophilia, and decrease in interstitial nephritis (arrow indicated leukocytic infiltration), as showed by kidney histopathology. Therefore, Vitamin E should be taken with Memantine to decrease its side effects.
\end{abstract}

Keywords: Memantine, neuropsychiatric diseases, vitamin E.

\section{Introduction}

Antioxidants have been defined as substances that prevent the genesis of reactive oxygen species (ROS) or other oxidants, and repair the damage they cause [1]. Antioxidant Defense System act as a stable and symmetrical framework and each depends on the activity of the other. In health, the stability lies somewhat in support of the reactive species so that they can accomplish their biological roles. Repair systems protect against damage which happens at a low level even in healing individual [2]. Antioxidant is a molecule that prohibits the oxidation of other molecules. Oxidation reaction means that chemical reaction transport electrons or hydrogen from a substance to an oxidizing agent. Oxidation reactions can output free radicals. In turn, these radicals can begin a chain reaction. The chain reaction which occurs in a cell can lead to damage or death to the cell. The role of antioxidants is to hinder these chain reactions by removing free radical intermediates, and prohibit other oxidation reactions. Antioxidants are often reducing agents such as anthills, ascorbic acid, or polyphenols, tocopherols and thiols [3]. The antioxidant defenses consist of a low molecular mass antioxidant such as Vit. E and

*Corresponding author email: (samarantar38@yahoo.com), Pharmacology Department, Faculty of Pharmacy, Horus university. enzymes e.g. SOD, CAT, GPX. The mission of antioxidant enzymes is to protect tissues and body fluids from damage by ROS/RNS whether produced physiologically or as a response to inflammation, infection or disease [4]. Vitamin E (Vit. E) is an important antioxidant in a biological system that decreases the peroxidation of un-structural lipids by a chain breaking free radical (FR), so it gives share in the stability of cellular membranes [5]. Vitamin E ( $\alpha$ - Tocopherol) is the most important lipid phase antioxidant [6]. Memantine is an uncompetitive N-methyl-Daspartate receptor antagonist with moderate affinity. Memantine mechanism's of action is neuroprotective and potentially therapeutic in several neuropsychiatric diseases. Memantine was approved that it had nephrotoxicityhepatotoxicity in rats. This review covers key studies of hepato-nephro protective effects of vitamin $\mathrm{E}(1 \mathrm{mg} / \mathrm{kg}$, P.O. once daily) against Memantine $(0.36 \mathrm{mg} / \mathrm{kg}$, P.O. once daily) toxicity for three weeks when vitamin $\mathrm{E}$ was co-administered with Memantine. Then tissue and blood samples were collected and the protective effect of vitamin $\mathrm{E}$ on liver and kidney appreciated through measuring biochemical constituents in sera such as serum 
creatinine, urea levels, liver injury biomarkers as serum alanine aminotransferase (ALT), aspartate aminotransferase (AST), alkaline phosphatase (ALP), total proteins, albumin and total bilirubin and oxidative stress biomarkers such as catalase (CAT), superoxide dismutase (SOD), glutathione peroxidase (GPX) and malondialdehyde (MDA) (marker of lipid peroxidation). The obtained results indicated that vitamin $\mathrm{E}$ has hepato-nephro protection through prohibiting the raise in liver and kidney injury biomarkers, and also the current histo-pathological results enhanced this effect.

\section{Material and Methods}

\section{Drugs and chemicals}

Vitamin E (Vitamin E capsule) was supplied by PHARCO pharmaceutical CO., Alex., Egypt. And Vitamin E is dissolved in corn oil. Memantine (Namenda®) was supplied by Forest Laboratories, Inc., H. Lundbeck, Merz Pharma, Memantine was prepared in saline immediately before use.

\section{Animals}

Adult albino rats (150-200 g) were purchased from local breeder and were pliable free access to standard laboratory conditions and tap water throughout the acclimatization and experimental periods. Animals were maintained under standard situation of temperature about $30^{\circ} \mathrm{C}$ and wetness $(60 \pm$ $10 \%$ ) with regular $12 \mathrm{~h}$ light/12h dark cycle. The experimental procedure which was qualified in this study complies with the ethical principles and guidelines for the care and the use of laboratory animals adopted by the "Research Ethics Committee", Faculty of Veterinary Medicine, Zagazig University, Egypt.

\section{Experimental design}

Animals were randomly allocated into 4 groups ( $n=20 /$ group). Group 1 (control): rats received saline. Group 2 (Memantine): rats received Memantine $(0.36 \mathrm{mg} / \mathrm{k} \mathrm{g} /$ day, P.O.) once daily for successive 21 days, the dose calculated according to Paget and Barnes [7]. Group 3 (vitamin E): rats received vitamin E $(1 \mathrm{mg} / \mathrm{kg} /$ day, P.O) once daily for successive 21 days. Group 4(Memantine + vitamin E): rats received Memantine $(0.36 \mathrm{mg} / \mathrm{kg} / \mathrm{day}$,
P.O.) and vitamin E (1mg/kg/day, P.O) once daily for successive 21 days.

\section{Preparation of serum sample and tissue sampling}

At the end of the experiment (12 hrs. after the last dose), rats were sacrificed and the following samples were collected: Blood was collected and allowed to clot for 30 minutes at $25^{\circ} \mathrm{C}$. Thereafter, they were centrifuged at $3000 \mathrm{rpm}$ for $10 \mathrm{~min}$, and the top yellow layers of serum were pipetted off without distributing the white buffy layer. Serum was stored at -20 ${ }^{\circ} \mathrm{C}$ and thawed just before use for the determination of liver and kidney enzymes. The liver and the kidney of each rat were isolated and kept in 10\% phosphate-buffered formalin for histopathological evaluations.

\section{Biochemical markers of liver and Kidney injury}

Determination of serum alanine aminotransferase (ALT), aspartate aminotransferase (AST) activities was established according to the principles described previously [8,9], also evaluation of activity of serum alkaline phosphatase (ALP) was determined according to the principles mentioned before [10]. Evaluation of creatinine, urea and uric acid has been done according to the method described previously [11]. Determination of these parameters was carried out through commercial kits from Spectrum Diagnostics (Cairo, Egypt).

\section{Hepatic and nephro histopathological evaluation}

Liver and kidney tissues were fixed in $10 \%$ neutral buffered formalin solutions for $24 \mathrm{hrs}$. Then, tissue processing and paraffin blocks preparation were done. Masson's trichome and hematoxylin-eosin stains were used to evaluate fibrotic areas and necro inflammation activity according to the method of Ishak et al. [12].

\section{Biochemical markers of antioxidant activity}

Determination of catalase activity (CAT), superoxide dismutase activity (SOD), glutathione peroxidase activity (GPX) and malondialdehyde activity (MDA) by method according to the previous principles [13], [14], and [15]. 


\section{Statistical analysis}

The data were analyzed using prism version 6. Statistical evaluations of the results, except the histopathological results, were done by using methods as one way and two-way analysis of variance (ANOVA).

\section{Results}

\section{Effects of combination between Memantine $(0.36 \mathrm{mg} / \mathrm{kg}$, P.O. once daily) and Vit.E vitamin E (1mg/kg, P.O. once daily) and on biochemical markers of liver injury.}

Effects of combination between Memantine and Vit.E on ALT: in the first week, resulted in decrease in serum ALT level $(42.35 \pm 5.12 \mathrm{U} / \mathrm{L})$ compared with $(62.36 \pm 6.47 \mathrm{U} / \mathrm{L})$ for Memantine group. In the second week, resulted in decrease in serum ALT activity (52.37 \pm 7.49 U/L) compared with $(67.44 \pm 9.06 \mathrm{U} / \mathrm{L})$ for Memantine group. A significant decrease in serum ALT activity $(60.97 \pm 17.28 \mathrm{U} / \mathrm{L})$ compared with $(75.36 \pm 17.98 \mathrm{U} / \mathrm{L})$ for Memantine group was showed in the third week, comparing between the combination of Memantine and Vit.E; (42.35 $\pm 5.12 \mathrm{U} / \mathrm{L})$, $(52.37 \pm 7.49 \mathrm{U} / \mathrm{L})$ and $(60.97 \pm 17.28 \mathrm{U} / \mathrm{L})$ against control group $(32.60 \pm 2.70 \mathrm{U} / \mathrm{L})$ showed an obvious increase in the third weeks.

Effects of combination between Memantine and Vit. E on AST: In the first week, resulted in decrease in serum AST level $(58.35 \pm 3.08 \mathrm{U} / \mathrm{L})$ compared with $(85.33 \pm 11.40 \mathrm{U} / \mathrm{L})$ for Memantine group. In the second week, resulted in decrease in serum AST activity $(63.30 \pm 4.01 \mathrm{U} / \mathrm{L})$ compared with $(96.34 \pm 20.97 \mathrm{U} / \mathrm{L})$ for Memantine group. In the third week, resulted in a significant decrease in serum AST activity $(98.96 \pm 2.82 \mathrm{U} / \mathrm{L})$ compared with $(147.55 \pm 63.12 \mathrm{U} / \mathrm{L})$ for Memantine group. Comparing between the combination of Memantine and Vit.E; (58.35 $\pm 3.08 \mathrm{U} / \mathrm{L})$, $(63.30 \pm 4.01 \mathrm{U} / \mathrm{L})$ and $(98.96 \pm 2.82 \mathrm{U} / \mathrm{L})$ against control group $(34.33 \pm 1.18 \mathrm{U} / \mathrm{L})$ showed a significant raise in the second and the third weeks.

Effects of combination between Memantine and Vit.E on ALP: In the first week, resulted in decrease in serum ALP level (199.60 $\pm 4.92 \mathrm{U} / \mathrm{L})$ compared with (216.02 $\pm 0.50 \mathrm{U} / \mathrm{L})$ for Memantine group. In the second week, resulted in a significant decrease in serum AST activity $(195.41 \pm 12.40 \mathrm{U} / \mathrm{L})$ compared with (244.07 $\pm 7.13 \mathrm{U} / \mathrm{L})$ for Memantine group. In the third week, resulted in a significant decrease in serum ALP activity $(244.13 \pm 71.84$ U/L) compared with (335.75 $\pm 46.63 \mathrm{U} / \mathrm{L})$ for Memantine group. Comparing between the combination of

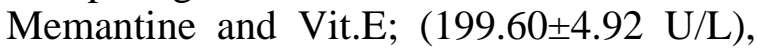
$(195.41 \pm 12.40 \mathrm{U} / \mathrm{L})$ and $(244.13 \pm 71.84$ U/L) against control group (177.03 \pm 11.54 $\mathrm{U} / \mathrm{L}$ ) produced a high increase only in the third week.

Effects of combination between Memantine and Vit.E on total protein: In first week, resulted in an increase in total protein level $(6.56 \pm 0.51 \mathrm{~g} / \mathrm{dl})$ compared with $(6.17 \pm 0.23 \mathrm{~g} / \mathrm{dl})$ for Memantine group. In second week, resulted in an increase in total protein activity $(6.49 \pm 0.48 \mathrm{~g} / \mathrm{dl})$ compared with $(5.41 \pm 0.49 \mathrm{~g} / \mathrm{dl})$ for Memantine group. In third week, resulted in resulted in an increase in total protein activity $(5.97 \pm 0.06$ $\mathrm{g} / \mathrm{dl})$ compared with $(4.79 \pm 0.14 \mathrm{~g} / \mathrm{dl})$ for Memantine group. Comparing between the combination of Memantine and Vit.E; $(6.56 \pm 0.51 \mathrm{~g} / \mathrm{dl}), \quad(6.49 \pm 0.48 \mathrm{~g} / \mathrm{dl}) \quad$ and $(5.97 \pm 0.06 \mathrm{~g} / \mathrm{dl})$ against control group $(6.73 \pm 0.03 \mathrm{~g} / \mathrm{dl})$ generated an obvious decline only in the third week. 
Table 1: The effect of Vit.E (1mg/kg, P.O. once daily), Memantine $(0.36 \mathrm{mg} / \mathrm{kg}$, P.O. once daily) and their combination on liver parameters of rats at 1st, 2 nd and 3rd weeks post-treatment

\begin{tabular}{|c|c|c|c|c|c|c|c|c|c|c|}
\hline & & AST & ALP & ALT & $\begin{array}{c}\text { Total. } \\
\text { Bilirubin } \\
\end{array}$ & $\begin{array}{c}\text { Direct. } \\
\text { Bilirubin } \\
\end{array}$ & Albumin & Globulin & A/G ratio & $\begin{array}{c}\text { Total } \\
\text { protein }\end{array}$ \\
\hline \multirow{8}{*}{ 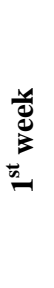 } & \multirow{2}{*}{ Control } & 34.33 & 177.03 & 32.60 & 0.66 & 0.14 & 4.01 & 2.30 & 1.81 & 6.73 \\
\hline & & \pm 1.18 & \pm 11.5 & \pm 2.70 & \pm 0.03 & \pm 0.01 & \pm 0.24 & \pm 0.21 & \pm 0.40 & \pm 0.39 \\
\hline & & 85.33 & 216.02 & 62.36 & 0.84 & 0.17 & 3.67 & 2.94 & 1.24 & 6.17 \\
\hline & Men & $\pm 11.40 * * *$ & $\pm 0.50 *$ & $\pm 6.47 * * * *$ & $\pm 0.03 * * * *$ & $\pm 0.01 * * * *$ & \pm 0.25 & $\pm 0.20 * *$ & $\pm 0.11 * *$ & \pm 0.23 \\
\hline & $\mathrm{Vi}_{\mathrm{i}}$ & 34.15 & 175.58 & 32.32 & 0.67 & 0.14 & 4.13 & 2.30 & 1.87 & 6.74 \\
\hline & & 5 & \pm 11.0 & \pm 3.71 & \pm 0.09 & \pm 0.05 & \pm 0.55 & \pm 0.17 & \pm 0.38 & \pm 0.92 \\
\hline & Memantine+ & 68.35 & 199.60 & 42.35 & 0.81 & 0.16 & 3.69 & 2.64 & 1.36 & 6.56 \\
\hline & Vit.E & \pm & $\pm 4.92^{\&}$ & $\pm 5.12^{\& \&}$ & $\pm 0.06^{\text {\&\&\& } \&}$ & \pm 0.01 & \pm 0.29 & \pm 0.31 & \pm 0.11 & \pm 0.51 \\
\hline & Con & 34.33 & 179.09 & 32.60 & 0.66 & 0.14 & 4.01 & 2.30 & 1.81 & 6.73 \\
\hline & 20 & \pm 1.18 & \pm 20.5 & \pm 2.70 & \pm 0.03 & \pm 0.01 & \pm 0.24 & \pm 0.21 & \pm 0.40 & \pm 0.39 \\
\hline \multirow{8}{*}{ 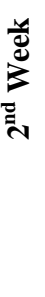 } & Men & 96.34 & 244.07 & 67.44 & 0.92 & 0.19 & 3.68 & 2.96 & 1.13 & 5.41 \\
\hline & Inen & $\pm 20.97 * * * *$ & $\pm 7.13 * * * *$ & $\pm 9.06 * * * *$ & $\pm 0.09 * * * *$ & $\pm 0.03 * * * *$ & $\pm 0.08 *$ & $\pm 0.08 * * * *$ & $\pm 0.18 * * *$ & $\pm 0.49^{*}$ \\
\hline & & 34.58 & 180.15 & 32.32 & 0.67 & 0.14 & 4.13 & 2.30 & 1.87 & 6.74 \\
\hline & & \pm 2.25 & \pm 18.5 & \pm 3.71 & \pm 0.09 & \pm 0.05 & \pm 0.55 & \pm 0.17 & \pm 0.34 & \pm 0.92 \\
\hline & Memantine+ & 93.30 & 195.41 & 52.37 & 0.77 & 0.17 & 3.37 & 2.50 & 1.34 & 6.49 \\
\hline & & \pm 4.01 & $\pm 12.4^{\& \& \& \&}$ & $\pm 7.49^{\& \& \&}$ & \pm 0.07 & \pm 0.01 & \pm 0.12 & \pm 0.34 & \pm 0.26 & \pm 0.48 \\
\hline & Contr & 34.33 & 14 & 32.60 & 0.66 & 0.13 & 4.01 & 2.30 & 1.81 & 6.73 \\
\hline & Contror & \pm 1.18 & 14 & \pm 2.70 & \pm 0.03 & \pm 0.02 & \pm 0.24 & \pm 0.21 & \pm 0.40 & \pm 0.39 \\
\hline \multirow{5}{*}{$\begin{array}{l}\frac{N}{d} \\
\sum_{n}^{\circ}\end{array}$} & Mem: & 147.55 & 335.75 & 75.36 & 0.97 & 0.21 & 3.21 & 3.18 & 1.00 & 4.79 \\
\hline & Memantıne & $\pm 63.1 * * * *$ & $\pm 46.3 * * * *$ & $\pm 17.98 * * * *$ & $\pm 0.15^{* *}$ & $\pm 0.02 * * * *$ & \pm 0.31 *** & \pm 0.18 *** & $\pm 0.06^{* *}$ & $\pm 0.14 * *$ \\
\hline & Vit $E$ & 35.21 & 149.51 & 32.32 & $67+009$ & 0.14 & 4.13 & 2.30 & 1.87 & 6.74 \\
\hline & & \pm 1.53 & \pm 33.6 & \pm 3.71 & $1 \pm 0.09$ & \pm 0.05 & \pm 0.55 & \pm 0.17 & \pm 0.83 & \pm 0.92 \\
\hline & $\begin{array}{c}\text { Memantine+ } \\
\text { Vit.E }\end{array}$ & $\begin{array}{c}98.96 \\
\pm 2.82^{\& \& \&}\end{array}$ & $\begin{array}{c}244.13 \\
\pm 71.8^{\& \& \& \&}\end{array}$ & $\begin{array}{c}60.97 \\
+17.28^{\& \& \& \&}\end{array}$ & $\begin{array}{c}0.71 \\
\pm 0.10^{\& \& \& \&}\end{array}$ & $\begin{array}{c}0.18 \\
\pm 0.02^{\& \& \& \&}\end{array}$ & $\begin{array}{c}3.10 \\
\pm 0.36\end{array}$ & $\begin{array}{c}2.72 \\
\pm 0.29^{\& \& \& \&}\end{array}$ & $\begin{array}{c}1.26 \\
\pm 0.04\end{array}$ & $\begin{array}{c}5.97 \\
\pm 0.06\end{array}$ \\
\hline
\end{tabular}

Table2: The effect of Vit. E (1mg P.O. once daily), Memantine (0.36mg P.O. once daily) and their combination on Kidney parameters of rats at 1st, 2nd and 3rd weeks post-treatment.

\begin{tabular}{cllll}
\hline & & Creatinine & Urea & Uric Acid \\
\hline \multirow{2}{*}{$\mathbf{1}^{\text {st }}$ week } & Control & $0.60 \pm 0.05$ & $17.82 \pm 0.34$ & $2.25 \pm 0.14$ \\
& Vit. E & $0.76 \pm 0.05^{* *}$ & $25.84 \pm 4.96^{* *}$ & $3.58 \pm 0.60^{* *}$ \\
& Memantine + Vit. E & $0.62 \pm 0.05$ & $17.38 \pm 0.83$ & $2.30 \pm 0.55$ \\
& Control & $0.65 \pm 0.05$ & $22.94 \pm 1.28$ & $2.80 \pm 0.55$ \\
$2^{\text {nd }}$ & Memantine & $0.60 \pm 0.05$ & $17.82 \pm 0.34$ & $2.25 \pm 0.14$ \\
Week $^{*}$ & Vit. E & $0.90 \pm 0.10^{* * * *}$ & $35.47 \pm 5.03^{* * * *}$ & $3.91 \pm 0.54^{* * * *}$ \\
& Memantine + Vit. E & $0.62 \pm 0.05$ & $17.38 \pm 0.83$ & $2.30 \pm 0.55$ \\
\multirow{2}{*}{$\mathbf{3}^{\text {rd }}$} & Control & $0.70 \pm 0.10^{\& \& \& \&}$ & $29.92 \pm 3.29^{\&}$ & $3.25 \pm 0.38^{\&}$ \\
$\mathbf{W e k}^{*}$ & Memantine & $0.60 \pm 0.05$ & $17.82 \pm 0.34$ & $2.25 \pm 0.14$ \\
& Memantine + Vit. E & $0.93 \pm 0.07^{* * * *}$ & $47.82 \pm 7.85^{* * * *}$ & $3.98 \pm 0.43^{* * * *}$ \\
\hline
\end{tabular}

Effect of combination between Memantine and Vit. E on total bilirubin: in the first week, resulted in decrease in total bilirubin level $(0.81 \pm 0.06 \mathrm{mg} / \mathrm{dl}) \quad$ compared with $(0.84 \pm 0.03 \mathrm{mg} / \mathrm{dl})$ for Memantine group. In the second week, resulted in decrease in total bilirubin activity $(0.77 \pm 0.07 \mathrm{mg} / \mathrm{dl})$ compared with $(0.92 \pm 0.09 \mathrm{mg} / \mathrm{dl})$ for Memantine group. In the third week, resulted in decrease in total bilirubin activity $(0.71 \pm 0.10 \mathrm{mg} / \mathrm{dl})$ compared with $(0.97 \pm 0.15 \mathrm{mg} / \mathrm{dl})$ for Memantine group. Comparing between the combination of Memantine and Vit. E group; $(0.81 \pm 0.06 \mathrm{mg} / \mathrm{dl}), \quad(0.77 \pm 0.07 \mathrm{mg} / \mathrm{dl}) \quad$ and $(0.71 \pm 0.10 \mathrm{mg} / \mathrm{dl})$ against control group $(0.66 \pm 0.03 \mathrm{mg} / \mathrm{dl})$ produced an obvious decline only in the third week. 
Effect of combination between Memantine and Vit. E on total bilirubin: in the first week, resulted in decrease in direct bilirubin level $(0.16 \pm 0.01 \mathrm{mg} / \mathrm{dl})$ compared with for $(0.17 \pm 0.01 \mathrm{mg} / \mathrm{dl})$ for Memantine group. In the second week, resulted in decrease in direct bilirubin activity $(0.17 \pm 0.01 \mathrm{mg} / \mathrm{dl})$ compared with $(0.19 \pm 0.03 \mathrm{mg} / \mathrm{dl})$ for Memantine group. In the third week, resulted in an increase in direct bilirubin activity $(0.18 \pm 0.02 \mathrm{mg} / \mathrm{dl})$ compared with $(0.21 \pm 0.02 \mathrm{mg} / \mathrm{dl})$ for Memantine group. Comparing between the combination of Memantine and Vit.E group $(0.16 \pm 0.01 \mathrm{mg} / \mathrm{dl}), \quad(0.17 \pm 0.01 \mathrm{mg} / \mathrm{dl}) \quad$ and $(0.18 \pm 0.02 \mathrm{mg} / \mathrm{dl})$ against control group $(0.14 \pm 0.01 \mathrm{mg} / \mathrm{dl})$ showed an excess increase in the three weeks.

Effect of combination between Memantine and Vit. E on albumin: In the first week, resulted in an increase in albumin level $(3.69 \pm 0.29 \mathrm{~g} / \mathrm{dl})$ compared with $(3.67 \pm 0.25 \mathrm{~g} / \mathrm{dl})$ for Memantine group. In the second week, resulted in an increase in albumin activity $(3.37 \pm 0.12 \mathrm{~g} / \mathrm{dl})$ compared with $(3.1 \pm 0.08 \mathrm{~g} / \mathrm{dl})$ for Memantine group. In the third week, resulted in resulted in an increase in albumin activity $(3.10 \pm 0.36 \mathrm{~g} / \mathrm{dl})$ compared with $(2.81 \pm 0.31 \mathrm{~g} / \mathrm{dl})$ for Memantine group. Comparing between the combination of Memantine and Vit. E group $(3.69 \pm 0.29 \mathrm{~g} / \mathrm{dl})$, $(3.37 \pm 0.12 \mathrm{~g} / \mathrm{dl})$ and $(3.10 \pm 0.36 \mathrm{~g} / \mathrm{dl})$ against control group $(4.01 \pm 0.24 \mathrm{~g} / \mathrm{dl})$ produced a significant raise only in the third week.

Effect of combination between Memantine and Vit. E on globulin: In the first week, resulted in decrease in globulin level $(2.64 \pm 0.31 \mathrm{~g} / \mathrm{dl}) \quad$ compared with $(2.94 \pm 0.20 \mathrm{~g} / \mathrm{dl})$ for Memantine group. In the second week, resulted in decrease in globulin activity $\quad(2.50 \pm 0.34 \mathrm{~g} / \mathrm{dl}) \quad$ compared with $(2.96 \pm 0.08 \mathrm{~g} / \mathrm{dl})$ for Memantine group. In the third week, resulted in decrease in globulin activity $(2.72 \pm 0.29 \mathrm{~g} / \mathrm{dl})$ compared with $(3.18 \pm 0.18 \mathrm{~g} / \mathrm{dl})$ for Memantine group. Comparing between the combination of Memantine and Vit.E group $(2.64 \pm 0.31 \mathrm{~g} / \mathrm{dl})$, $(2.50 \pm 0.34 \mathrm{~g} / \mathrm{dl})$ and $(2.72 \pm 0.29 \mathrm{~g} / \mathrm{dl})$ against control group $(2.30 \pm 0.21 \mathrm{~g} / \mathrm{dl})$ the outcome showed a significant raise in the second and third weeks

\section{Effects of Memantine $(0.36 \mathrm{mg} / \mathrm{kg}$, P.O. once daily), vitamin $E$ (1mg/kg, P.O. once daily) and their combination on biochemical markers of kidney injury.}

The combination between Memantine and Vit.E on creatinine: In the first week, resulted in decrease in creatinine level $(0.65 \pm 0.05$ $\mathrm{mg} / \mathrm{dl})$ compared with $(0.76 \pm 0.05 \mathrm{mg} / \mathrm{dl})$ for Memantine group. In the second week, resulted in decrease in creatinine activity $(0.70$ $\pm 0.10 \mathrm{mg} / \mathrm{dl})$ compared with $(0.90 \pm 0.10 \mathrm{mg} / \mathrm{dl})$ for Memantine group. In the third week, resulted in decrease in creatinine activity $(0.76 \pm 0.05 \mathrm{mg} / \mathrm{dl})$ compared with $(0.98 \pm 0.07$ $\mathrm{mg} / \mathrm{dl}$ ) for Memantine group.

The combination between Memantine and Vit.E on uric acid: In the first week, resulted in decrease in uric acid level $(2.80 \pm 0.55 \mathrm{mg} / \mathrm{dl})$ compared with $(3.58 \pm 0.60 \mathrm{mg} / \mathrm{dl})$ for Memantine group. In the second week, resulted in decrease in uric acid activity $(3.25 \pm 0.38 \mathrm{mg} / \mathrm{dl})$ compared with $(3.81 \pm 0.54$ $\mathrm{mg} / \mathrm{dl})$ for Memantine group. In third week, resulted in decrease in uric acid activity $(3.41 \pm 0.14 \mathrm{mg} / \mathrm{dl})$ compared with $(3.98 \pm 0.43$ $\mathrm{mg} / \mathrm{dl}$ ) for the Memantine group.

The combination between Memantine and Vit.E on urea: In the first week, resulted in decrease in urea level $(22.94 \pm 1.28 \mathrm{mg} / \mathrm{dl})$ compared with $(25.84 \pm 4.96 \mathrm{mg} / \mathrm{dl})$ for Memantine group. In the second week, resulted in an increase in urea activity $(29.92 \pm 3.29 \mathrm{mg} / \mathrm{dl})$ compared with $(35.47 \pm 5.03 \mathrm{mg} / \mathrm{dl})$ for Memantine group. In the third week, resulted in an increase in urea activity $(39.02 \pm 1.6 \mathrm{mg} / \mathrm{dl})$ compared with $(47.82 \pm 7.85 \mathrm{mg} / \mathrm{dl})$ for Memantine group. Comparing between the combination of Memantine and Vit. E $(22.94 \pm 1.28 \mathrm{mg} / \mathrm{dl})$, $(29.92 \pm 3.29 \mathrm{mg} / \mathrm{dl})$ and $(39.02 \pm 1.6 \mathrm{mg} / \mathrm{dl})$ against for $(17.82 \pm 0.34 \mathrm{mg} / \mathrm{dl})$ control group produced a high increase in the second and third weeks. 
Table (3)The effect of Vit.E (1mg/kg, P.O. once daily), Memantine $(0.36 \mathrm{mg} / \mathrm{kg}$, P.O. once daily) and their combination on antioxidant enzymes activities of rats at $1^{\text {st }}, 2^{\text {nd }}$ and $3^{\text {rd }}$ weeks post-treatment

\begin{tabular}{|c|c|c|c|c|c|}
\hline & & MDA & SOD & CAT & GPX \\
\hline \multirow{4}{*}{$\begin{array}{c}\mathbf{1}^{\text {st }} \\
\text { week }\end{array}$} & Control & $0.14 \pm 0.07$ & $0.21 \pm 0.03$ & $0.22 \pm 0.03$ & $0.25 \pm 0.03$ \\
\hline & Memantine & $0.22 \pm 0.07$ & $0.18 \pm 0.01$ & $0.16 \pm 0.09$ & $0.20 \pm 0.04$ \\
\hline & Vit. E & $0.14 \pm 0.01$ & $0.25 \pm 0.15$ & $0.28 \pm 0.04$ & $0.27 \pm 0.02$ \\
\hline & Memantine + Vit. E & $0.17 \pm 0.07$ & $0.22 \pm 0.03$ & $0.19 \pm 0.03$ & $0.22 \pm 0.02$ \\
\hline \multirow{4}{*}{$\begin{array}{c}2^{\text {nd }} \\
\text { Week }\end{array}$} & Control & $0.14 \pm 0.07$ & $0.21 \pm 0.03$ & $0.22 \pm 0.03$ & $0.25 \pm 0.03$ \\
\hline & Memantine & $0.38 \pm 0.10^{* * * *}$ & $0.13 \pm 0.06^{* * *}$ & $0.11 \pm 0.03^{*}$ & $0.14 \pm 0.06^{* * *}$ \\
\hline & Vit. E & $0.14 \pm 0.01$ & $0.29 \pm 0.08$ & $0.32 \pm 0.04$ & $0.32 \pm 0.05$ \\
\hline & Memantine + Vit. E & $0.21 \pm 0.08^{\& \& \& \&}$ & $0.18 \pm 0.05^{\& \&}$ & $0.18 \pm 0.04^{\&}$ & $0.20 \pm 0.03$ \\
\hline \multirow{4}{*}{$\begin{array}{c}3^{\text {rd }} \\
\text { Week }\end{array}$} & Control & $0.14 \pm 0.07$ & $0.21 \pm 0.03$ & $0.22 \pm 0.03$ & $0.25 \pm 0.03$ \\
\hline & Memantine & $0.48 \pm 0.05^{* * * *}$ & $0.09 \pm 0.04^{* * * *}$ & $0.08 \pm 0.05^{* * *}$ & $0.10 \pm 0.05^{* * * *}$ \\
\hline & Vit. E & $0.14 \pm 0.01$ & $0.31 \pm 0.03$ & $0.38 \pm 0.04$ & $0.37 \pm 0.01$ \\
\hline & Memantine + Vit. E & $0.28 \pm 0.04^{\& \& \& \&}$ & $0.17 \pm 0.05^{\& \& \& \&}$ & $0.20 \pm 0.06^{\& \&}$ & $0.21 \pm 0.09^{\& \&}$ \\
\hline
\end{tabular}

Effects of Memantine $(0.36 \mathrm{mg} / \mathrm{kg}$, P.O. once daily), vitamin $E$ (1mg/kg, P.O. once daily) and their combination on biochemical markers of antioxidant enzymes.

The combination between Memantine and Vit.E on CAT: In the first week, resulted in an increase in catalase activity $(0.19 \pm 0.03 \mathrm{U} / \mathrm{ml})$ compared with $(0.16 \pm 0.09 \mathrm{U} / \mathrm{ml})$ for Memantine group. In the second week, resulted in an increase in catalase activity $(0.18 \pm 0.04 \mathrm{U} / \mathrm{ml})$ compared with $(0.11 \pm$ $0.03 \mathrm{U} / \mathrm{ml}$ ) for Memantine group. In the third week, resulted in an increase in catalase activity $(0.20 \pm 0.06 \mathrm{U} / \mathrm{ml})$ compared with $(0.08 \pm 0.05 \mathrm{U} / \mathrm{ml})$ for Memantine group. Comparing between the combination of Memantine and Vit.E $(0.19 \pm 0.03 \mathrm{U} / \mathrm{ml}),(0.18 \pm$ $0.04 \mathrm{U} / \mathrm{ml})$ and $(0.20 \pm 0.06 \mathrm{U} / \mathrm{ml})$ against for vitamin E group $(0.28 \pm 0.04 \mathrm{U} / \mathrm{ml}), \quad(0.32 \pm$ $0.04 \mathrm{U} / \mathrm{ml})$ and $(0.38 \pm 0.04 \mathrm{U} / \mathrm{ml})$ generated an excess increase in the second and third week.

The combination between Memantine and Vit.E on SOD: In the first week, resulted in an increase in SOD activity $(0.22 \pm 0.03 \mathrm{U} / \mathrm{ml})$ compared with $(0.18 \pm 0.01 \mathrm{U} / \mathrm{ml})$ for Memantine group. In the second week, there is an increase in SOD activity $(0.18 \pm 0.05$ $\mathrm{U} / \mathrm{ml})$ compared with $(0.13 \pm 0.06 \mathrm{U} / \mathrm{ml})$ for Memantine group. In the third week, there is a decrease in SOD activity $(0.17 \pm 0.04 \mathrm{U} / \mathrm{ml})$ compared with $(0.09 \pm 0.04 \mathrm{U} / \mathrm{ml})$ for Memantine group. Comparing between the combination of Memantine and Vit.E
$(0.22 \pm 0.03 \mathrm{U} / \mathrm{ml}),(0.18 \pm 0.05 \mathrm{U} / \mathrm{ml})$ and $(0.17 \pm 0.04 \mathrm{U} / \mathrm{ml})$ against for vitamin $\mathrm{E}$ group $(0.25 \pm 0.15 \mathrm{U} / \mathrm{ml}) \quad(0.29 \pm 0.08 \mathrm{U} / \mathrm{ml}) \quad$ and $(0.31 \pm 0.03 \mathrm{U} / \mathrm{ml})$ produced in a high raise in the second and third week.

The combination between Memantine and Vit. E on GPX: In the first week, resulted in an increase in GPX activity $(0.22 \pm 0.02 \mathrm{U} / \mathrm{ml})$ compared with $(0.20 \pm 0.04 \mathrm{U} / \mathrm{ml})$ for Memantine group. In the second week, there is an increase in GPX activity $(0.20 \pm 0.03 \mathrm{U} / \mathrm{ml})$ compared with $(0.14 \pm 0.06 \mathrm{U} / \mathrm{ml})$ for Memantine group. In the third week, there is an increase in GPX activity $(0.21 \pm 0.09 \mathrm{U} / \mathrm{ml})$ compared with $(0.10 \pm 0.05 \mathrm{U} / \mathrm{ml})$ for Memantine group. Comparing between the combination of Memantine and Vit. E $(0.22 \pm 0.02 \mathrm{U} / \mathrm{ml}), \quad(0.20 \pm 0.03 \mathrm{U} / \mathrm{ml})$ and $(0.21 \pm 0.09 \mathrm{U} / \mathrm{ml})$ against for vitamin $\mathrm{E}$ group $(0.27 \pm 0.02 \mathrm{U} / \mathrm{ml}), \quad(0.32 \pm 0.05 \mathrm{U} / \mathrm{ml}) \quad$ and $(0.37 \pm 0.04 \mathrm{U} / \mathrm{ml})$ showed in an obvious increase in the second and third week.

The combination between Memantine and Vit. E on MDA: In the first week, resulted in decrease in MDA activity $(0.17 \pm 0.07 \mathrm{~mm} / \mathrm{L})$ compared with $(0.22 \pm 0.07 \mathrm{~mm} / \mathrm{L})$ for Memantine group. In the second week, resulted in decrease in MDA activity $(0.21 \pm$ $0.08 \mathrm{~mm} / \mathrm{L})$ compared with $(0.38 \pm 0.10 \mathrm{~mm} / \mathrm{L})$ for Memantine group. In the third week, resulted in a decrease in MDA activity $(0.28 \pm$ $0.04 \mathrm{~mm} / \mathrm{L})$ compared with $(0.48 \pm 0.05 \mathrm{~mm} / \mathrm{L})$ for Memantine group. Comparing between the 
combination of Memantine and Vit. E (0.17 \pm $0.07 \mathrm{~mm} / \mathrm{L}), \quad(0.21 \pm 0.08 \mathrm{~mm} / \mathrm{L})$ and $(0.28 \pm$ $0.04 \mathrm{~mm} / \mathrm{L})$ against $(0.14 \pm 0.07 \mathrm{~mm} / \mathrm{L})$ for vitamin $\mathrm{E}$ resulted in a significant decrease in the second and third week.

\section{Histopathological results of Liver in first week}

Liver of Memantine-treated animal (7th day sacrifice) showing centrolobular hypertrophy of the hepatocytes (arrow) and periportal vacuolation of hepatocytes (A). Liver of Memantine + Vit. E treated animal (7th day sacrifice) showing focal cell necrosis (arrow) and mild hepatocyte vacuolation (B).

\section{Histopathological results of Liver in second week}
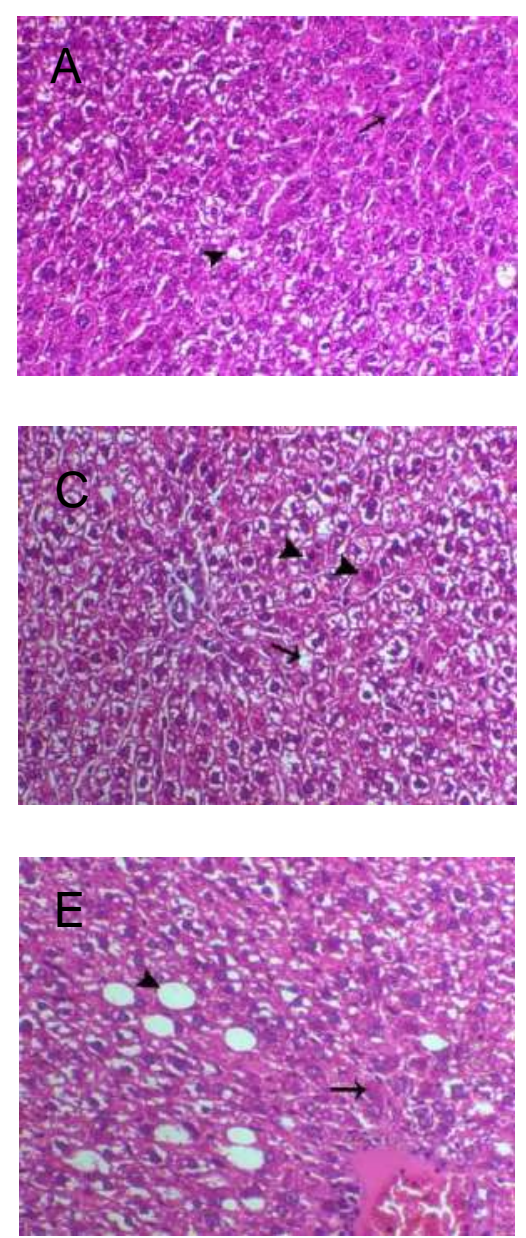

Liver of Memantine-treated animal (14th day sacrifice) showing numerous apoptotic cells (arrowhead) associated with hepatic vacuolation (C). Liver of (Memantine + Vit. E) treated animal (14th day sacrifice) showing mild degree of hepatic vacuolation and necrosis (D).

\section{Histopathological results of Liver in third week}

Liver of Memantine-treated animal (21st day sacrifice) showing hepatic steatosis (arrowhead) and increase the apoptotic and necrotic cells mostly within the centrolobular area (E). Liver of (Memantine + Vit. E) treated animal (21st day sacrifice) showing decrease hepatic vacuolation and necrosis $(F)$.
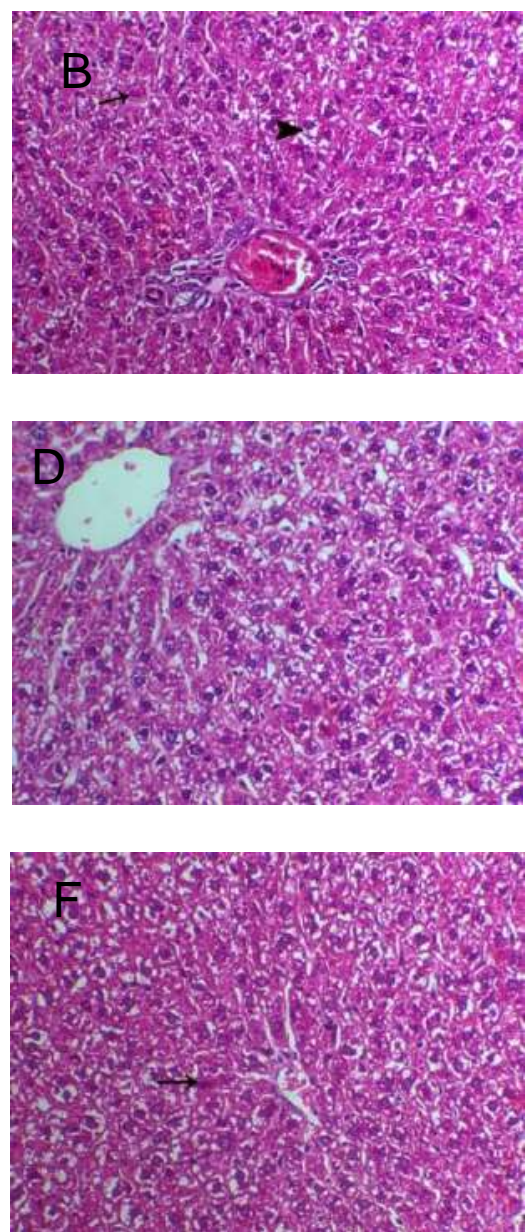

Figure 1: A: Liver of Memantine-treated animal (7th day sacrifice) showing centrolobular hypertrophy of the hepatocytes (arrow) and periportal vacuolation of hepatocytes (arrowhead), H\&E, X200. B: Liver of Memantine+Vit. E treated animal (7th day sacrifice) showing focal cell necrosis (arrow) and mild hepatocyte vacuolation (arrowhead), H\&E, X200. C: Liver of Memantine-treated animal (14th day sacrifice) showing diffuse hepatic vacuolation, H\&E, X200. D. Liver of (Memantine+Vit. E) treated animal (14th day sacrifice) showing mild degree of hepatic vacuolation and necrosis, H\&E, X200. E: Liver of Memantine-treated animal (21st day sacrifice) showing hepatic steatosis (arrowhead) and increase the apoptotic and necrotic cells mostly within the centrolobular area (arrow), H\&E, X200. F: Liver of (Memantine+Vit. E)treated animal (21st day sacrifice) showing decrease hepatic vacuolation and necrosis, H\&E, X200. 
Histopathological results of kidney in first week

Kidney of Memantine-treated animal (7th day sacrifice) showing degeneration of renal tubular with attempt of regeneration of the lining epithelial cells of the renal tubules (arrow), also periglomerular and peritubular few inflammatory cell infiltrations was noticed (G). Kidney of (Memantine+Vit.E) treated animal (7th day sacrifice) showing mild degeneration of the renal tubular epithelium (H).
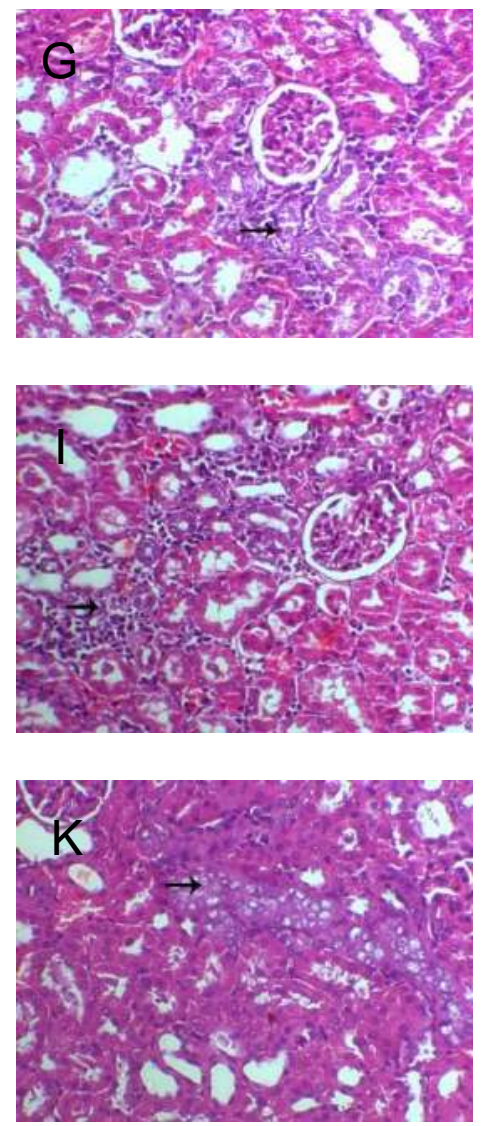

\section{Histopathological results of kidney in second} week

Kidney of Memantine-treated animal (14th day sacrifice) showing tubulo-interstitial nephritis represented by marked mononuclear cell infiltration (I). Kidney of (Memantine+Vit. E) treated animal (14th day sacrifice) showing normal renal glomeruli (arrow) and tubules (J).

\section{Histopathological results of kidney in third week}

Kidney of Memantine-treated animal (21st day sacrifice) showing tubular basophilia (K). Kidney of (Memantine+Vit.E) treated animal (21st day sacrifice) showing mild degree of tubular lining epithelium degeneration (L).
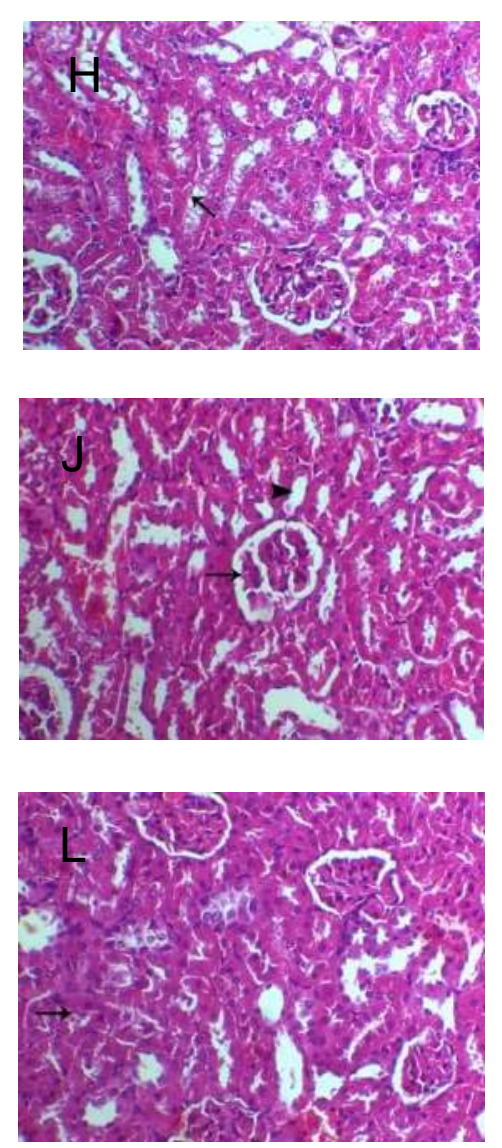

Figure 2: G: Kidney of Memantine-treated animal (7th day sacrifice) showing degeneration of renal tubular with attempt of regeneration of the lining epithelial cells of the renal tubules (arrow), also periglomerular and peritubular few inflammatory cell infiltrations was noticed, H\&E, X200. H: Kidney of Memantine+Vit. E treated animal (7th day sacrifice) showing mild degeneration of the renal tubular epithelium (arrow), H\&E, X200. I: Kidney of Memantinetreated animal (14th day sacrifice) showing tubulo-interstitial nephritis represented by marked mononuclear cell infiltration (arrow), H\&E, X200. J: Kidney of (Memantine+Vit. E)-treated animal (14th day sacrifice) showing normal renal glomeruli (arrow) and tubules (arrowhead), H\&E, X200. K: Kidney of Memantine-treated animal (21st day sacrifice) showing tubular basophilia (arrow), H\&E, X200. L: Kidney of (Memantine+Vit. E)-treated animal (21st day sacrifice) showing mild degree of tubular lining epithelium degeneration (arrow), H\&E, X200. 


\section{Discussion}

Chemical agents are showed to encourage hepatotoxicity and nephrotoxicity in humans. Drugs are investigated daily for their hepatoprotective and nephroprotective properties for example Vit. E. It is one of the most important antioxidant drugs due to its hepato-nephroprotective properties. This study identifies the hepato-nephroprotective effect of Vit. E. Vit. E has hepatoprotective effect as it expresses important functions in the membranes like blocking ROS damage in polyunsaturated fatty acids as a lipid soluble antioxidant and acting against damage caused to phospholipids as a membrane-stabilizing agent. It decreases the process of lipid peroxidation and protects against injury of liver. Vit. E decreases liver fibrosis, tumor necrosis factor, inflammation and hepatic porphyrin [12]. The previous observations explained the hepatoprotective role of Vit. E observed in our results.

Vit. E normalized levels of alanine aminotransferase, aspartate aminotransferase, alkaline phosphatase, serum bilirubin, glutathione superoxide dismutase, malondialdehyde and improved histopathological changes in the liver induced by chemical agents in the normal state or in the control group. The possible pathway can be explained through the structure, the 2position in the side chain makes it easier for the incorporation and detention of Vit. $\mathrm{E}$ in bio membranes, the position which is responsible for scavenging free radicals and terminating lipid peroxidation is the 6- position. Antioxidant effect is presented through protection of poly unsaturated fatty acid from oxidation by reactive oxygen species, stability of membrane and breaking of antioxidant chains that block Reactive Oxygen Species damage to membranes. So, we used Vit. E in a dose $(1 \mathrm{mg} / \mathrm{kg}$, P.O. once daily for 21 days) to clarify the hepatic-nephroprotective effect on rats. We noticed that, there is a rise in the activities of anti-oxidative stress enzymes (GPX, CAT and SOD) and significant decrease MDA activity.

The obtained histopathological results reveal that there is mild to moderate hepatic vacuolation and decrease the hepatic steatosis and the results according to the kidney, showed a mild degree of renal tubular epithelium degeneration than that observed by administration of Memantine. Aebi [13] found that the antioxidant effect of Vit.E in prior decrease activities of MDA in the renal cortex.

The administration of Vit. E with Memantine showed an obvious decline in action of serum ALT, AST, and ALP when contrasted with Memantine group. Nishikimi et al. [14] reported the anti-oxidative therapy, mainly using natural and synthetic antioxidants, performs a sensible therapeutic approach for the prevention and treatment of liver diseases due to the role of oxidative stress in contributing to initiation and progression of hepatic damage. Paglia and Valentine [15] reported that the antioxidant therapy has been considered to have the possibility of beneficial effects in the control of these liver diseases, antioxidants have produced mixed results in a number of clinical trials of efficacy. The most promising results to date are for vitamin $E$ therapy of NASH (nonalcoholic steatohepatitis) but some encouraging results have been obtained with antioxidant therapy of acute alcoholic hepatitis.

It was previously reported that antioxidant vitamin $\mathrm{E}$ prevent hepatic fibrosis in biliaryobstructed rats [16]. Oxidative stress may have a role in the pathogenesis of hepatic fibrosis in secondary biliary cirrhosis. It was previously found that the lipid peroxidation reaction might be normalized by Vit. E and also by the increased level of antioxidant enzymes, SOD, CAT and GPX related biochemical changes which conserves the cells from the high increased risk of peroxidative damage as a result from the administration of cytotoxic drugs[17]. Sanchez-Valle et al. [18] reported that the antioxidant Vit. $E$ reduced Memantine-induced oxidative stress and so has nephroprotective and hepatoprotective effect against Memantine toxicity. Hepatoprotective effects of Vit.E against malathion-induced mitochondrial dysfunction in rat liver was recorded before [19]. It was previously reported that Pre-treatment with Vit. E significantly reduced the elevated serum creatinine and urea levels and improved kidney histopathological picture [20]. These results prove that obtained before by who 
showed the protective role of tocotrienol against potassium dichromate-induced nephrotoxicity. Beytut et al. [21] reported that one of the ways in which $\alpha$-tocopherol is believed to stabilize membranes by forming a complex with the membrane lipids components that have a tendency to destabilize the bilayer structure thereby countering their effects and making the membrane more stable as also supported by the observed reduction of MDA and nitric oxide as well as increased glutathione. Another explanation of action of Vit.E to prohibit lipid peroxide radical was suggested by Beytut et al. [21] who suggested that $\alpha$-tocopherol treatment avoided oxidative damage, through its capacity to quickly and efficiently scavenge lipid peroxide radicals before they coming down the membrane lipids. Due to the fact that lipid peroxyl radicals react more faster (by four orders of magnitude) with $\alpha$-tocopherol than with membrane lipids.

\section{Conclusion}

It could be concluded that Vit. E has a protective effect against hepato-nephrotoxicity of Memantine which may attribute to decrease the harmful effects of Memantine by inhibiting free radical formation and by restoration of the antioxidant systems. The combination of Vit.E and Memantine showed better results than Memantine alone.

\section{Conflict of interest}

The authors declare no conflict of interest.

\section{References}

[1]Kosther, G.M.; Ottl.; Jauhiainen, M.; Enholm, C. and Esterbauer, H. (1995): Human plasma phospholipids transfer protein accelerates exchange/transfer of $\alpha$ tocopherol between lipoproteins and cells. Biochem.j.,305:659-667.

[2]Hallowell, B. (1995): Antioxidant characterization: Methodology and mechanism. Biochem. Pharmacol., 49 (10):1341-1348.

[3]Zidenberg-Cherr, S. and Keen, C.L. (1991): Trace element micronutrient, and free radical. In essential trace element in antioxidant processes. Springer, pp.107.
[4]Evans, P. and Halliwell, B. (2001): Micronutrients: oxidant/ antioxidant status. British J. of Nutrition, 85 (2): 567-574.

[5]Hallowell, B. (1995): Antioxidant characterization: Methodology and mechanism. Biochem. Pharmacol., 49 (10):1341-1348.

[6] Esterbauer, H.; Dieber-Rotheneder, M. and Striegl, G. (1991): Role of Vitamin E in preventing the oxidation of low-dentisty lipoprotein. Am. J. Clin. Nutr., 53:314s$321 \mathrm{~s}$.

[7]Paget, G.E. and Barnes, J.M. (1964): Evaluation of Drug Activities: Pharmacometrics, Laurence and Bacharach, Voll, Academic Press, New York P. 133-166.

[8]Bergmeyer, H.U. Horder, M. Rej, R. (1986) IFCC method for alanine aminotransferase (L-alanine: 2-oxogluconate aminotransferase, EC 2.6.1.2), J. Clin. Chem. Clin. Biochem. 24 481-495.

[9]Bergmeyer, H.U. Horder, M. Rej, R. (1986): IFCC method for aspartate aminotransferase (L-aspartate: 2oxogluconate aminotransferase, EC 2.6.1.1), J. Clin. Chem. Clin. Biochem. 24: 497-510.

[10]Tietz, N.W. Rinker, A.D. Shaw, L.M. (1983): IFCC methods for the measurement of catalytic concentration of enzymes part 5. IFCC method for alkaline phosphatase (orthophosphoric -monoester phosphohydrase, alkaine optimum, EC 3.1. 3. 1), J, Clin. Chem. Clin. Biochem. 21: 731-748.

[11]Pagana, Kathleen D. Mosby's Manual of Diagnostic and Laboratory Tests. St. Louis Mosby, Inc., 1998 and Rebecca J.F Gale Encyclopedia of Medicine. 2002.

[12]Adaramoye, O.A.; Osaimoje, D.O.; Akinsanya, M.A. and Fafunso, M.A. (2008): Changes in antioxidant status and biochemical indices after acute administration of artemether, artemetherlumefantrine and halofantrine in rats. Basic. Clin. Pharmacol. Toxicol., 102 (4): 412-418. 
[13]Aebi, H. (1984): Colourmetrical determination of Catalase activity. Methods Enzymol., 105:121-126.

[14]Nishikimi, M.; Roa, N.A. and Yogi, K. (1972): Measurement of superoxide dismutase. Bioch. Btoph. Res. Commun., 46:849-85.

[15]Paglia, D.E and Valentine, W.N. (1967): Studies on quantitative and qualitative characterization of erythrocyte glutathione peroxidase. J. Lab. Clin. Med., 70(1): 158169.

[16] Bradford, A.; Atkinson, J.; Fuller, N. and Rand, R.P. (2003): The effect of Vitamin $\mathrm{E}$ on the structure of membrane lipid assemblies. J. Lipid Res., 44(10);19401945. 18.

[17]Derakhshanfar, A.; Bidadkosh, A. and Kazeminia, S. (2007): Vitamin E protection against Memantine induced nephrotoxicity in rats: a biochemical and histopathologic study. Iranian Journal of Veterinary Research, 8 (3):231-238.

[18]Sanchez-Valle V., Chavez-Tapia N.C., Uribe M., Mendez-Sanchez N (2012): Role of oxidative stress and molecular changes in liver fibrosis: A review. Curr. Med. Chem.; 19:4850-4860.

[19] Medina, J. and Moreno-Otero R. (2005): Pathophysiological basis for antioxidant therapy in chronic liver disease. Drugs.; 65:2445-2461.

[20]Parola, M., Leonarduzzi, G., Biasi, F., Albano, E., Biocca, M.E., Poli, G., Dianzani, M.U. (1992): Vitamin E dietary supplementation protects against carbon tetrachloride-induced chronic liver damage and cirrhosis. Hepatology; 16:1014-1021.

[21] Beytut, E.; Erisir, M. and Ahsakal, M. (2003): Effects of additional, Vitamin E and selenium supply on antioxidative defense mechanisms in the kidney of rats treated with high doses of glucocorticoid. Cell Biochem. Funct., 22 (1): 59-65.

[22]Dysken, M.W., Guarino P.D., Vertrees J.E. (2013): Vitamin E and Memantine in Alzheimer's disease: clinical trial methods and baseline data published online April 2013. Alzheimers Dement. doi: 10.1016/j.jalz.2013.01.014. PubMed

[23]Meagher, E.A., Barry, O.P., Lawson, J.A., Rokach, J., FitzGerald, G.A. (2001): Effects of Vitamin E on lipid peroxidation in healthy persons. JAMA. 285(9):117882.

[24]Khan, M.R.; Badar, I. and Siddiguah, A. (2011): Prevention of hepatorenal toxicity with sonchus asper in Memantine treated rats. Complementary and Alternative Medicine, 11:113.

[25]Kagan, V.E. and Tyurina, Y.Y. (1998): Recycling and redox cycling of phenolic antioxidants, towards prolongation of the healthy life span. Ann. N. Y. Acad. Sci., 854:425-34.

[26] Halliwel, B. Gutteridge J.M.C. (2002): Free radicals in biology and medicine, vol. 3, Oxford University Press Inc., New York, pp. 105-245. 


$$
\begin{aligned}
& \text { الملخص العربي } \\
& \text { الأثار الوقائيه لفيتامين هـ علي الأثثار الضارة للميمانتين }
\end{aligned}
$$

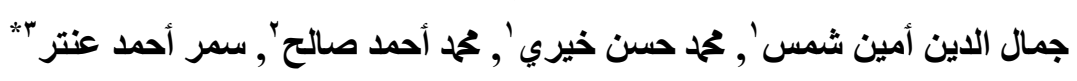

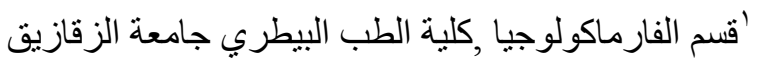

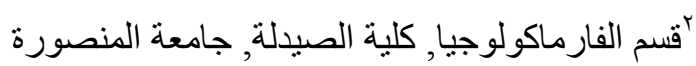

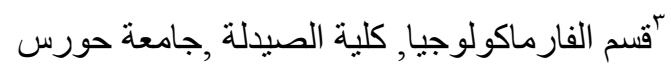

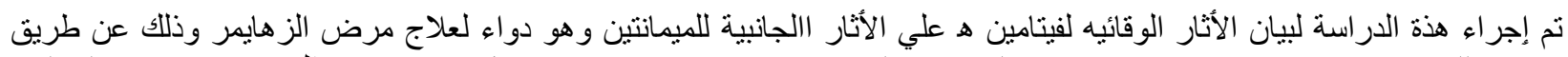

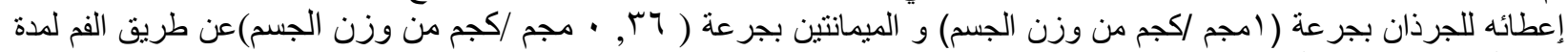

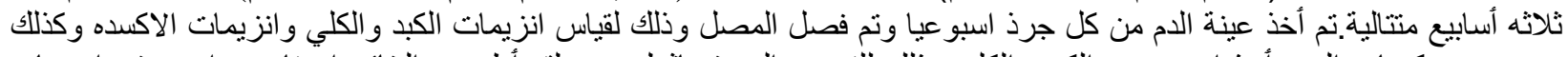

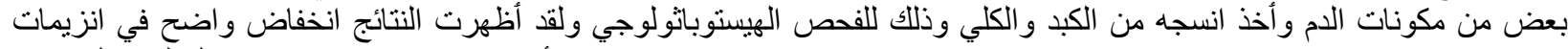

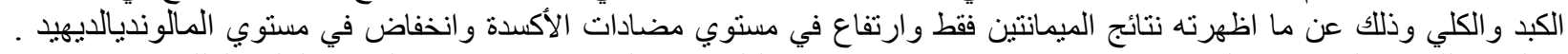

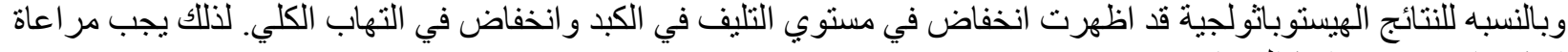

